- субъективные проблемы: несоответствие материала возрастным особенностям младших школьников, недостаточное внимание к индивидуальным особенностям по типу памяти учащихся, проведение однотипных видов работы на уроках, недостаточное применение учителями начальных классов и младшими школьниками специальных приемов запоминания, бесконтрольная подготовка домашних заданий со стороны родителей младших школьников, отсутствие определенных знаний и умений у родителей по организации запоминания учебного материала учащимися при выполнении домашних заданий, отсутствие у родителей знания о типе памяти своего ребенка и причинах запоминания учебного материала в соответствии с индивидуальными особенностями.

Память в младшем школьном возрасте развивается благодаря работе учителя по развитию памяти учащихся, систематической и целенаправленной деятельности над процессом запоминания учебного материала через применение специальных способов и приемов, а также через обучение этим приемам учащихся и их родителей. Большую роль играет осознание учеником цели запоминания, потому что в младшем школьном возрасте запоминание осуществляется неосознанно и в большинстве случаев механически, т.е. без какой-либо цели, которую должен ставить перед собой младший школьник. Также задача учителя состоит в том, чтобы следить за способами запоминания учебного материала учащимися и уметь определять, как каждый младший школьник запоминает тот, или иной учебный материал и помогать родителям учащихся в этом вопросе.

$$
* * *
$$

1. Блонский П.П. Память и мышление. - М., 2010.

2. Громов В.В. Память - как психологический процесс // Начальная школа. - 2011. - №3. - С.10-12.

3. Давыдова Е.С. Проблемы формирования памяти в процессе учебной деятельности // Школьный психолог. - 2012. - №1. - С. 24-25.

4. Занков Л.В. Память школьника / Л.В. Занков. - М., 2012.

5. Зинченко П.И. Непроизвольное запоминание- М.: Просвещение, 2011.

6. Ипполитов Ф.В. Память школьника / Ф.В. Ипполитов. - М.: Просвещение, 2014.

7. Крутецкий, В.А. Процессы запоминания у младших школьников. - М.: Просвещение, 2011. -352 с.

8. Лайло В.В. Развитие памяти и повышение грамотности. - М, Дрофа, 2010.

9. Лурия А.Р. Маленькая книжка о большой памяти. - М.: Просвещение, 2011.

10. Микерова Г.Ж. Особенности взаимодействия принципов наглядности, систематичности и последовательности в технологии укрупненных дидактических единиц. Диссертация на соискание ученой степени кандидата педагогических наук, Краснодар, 1999.

11. Омельченко Л.В. Использование приемов мнемотехники в развитии связной речи // Логопед. 2008. - № 4. - C. 102.

12. Смирнов А.А. Психология запоминания. - М., 2009.

13. Чутко Н.Я. Развитие памяти школьника / Н.Я. Чутко. - М.: Педагогика, 2008.

\title{
Никитовская Г.В. \\ Использование элементов педагогического коучинга в дополнительном профессиональном образовании
}

Приднестровский государственный университет им. Т.Г. Шевченко (Молдова, Приднестровье, Тирасполь)

doi 10.18411/spc-04-03-2018-13

idsp 000001:spc-04-03-2018-13

\section{Аннотация}

В статье рассматривается потенциал педагогического коучинга как перспективной образовательной технологии. Описываются принципы и приемы использования элементов педагогического коучинга в дополнительном 


\section{профессиональном образовании как инструмента саморазвития, самоактуализации и самореализации личности обучающегося. \\ Ключевые слова: дополнительное профессиональное образование, педагогический коучинг, самоактуализация, самореализация личности}

\section{Abstract}

The article considers the potential of pedagogical coaching as a promising educational technology. The principles and methods of using the elements of pedagogical coaching in additional professional education as an instrument of self-development, self-actualization and self-realization of the student are described.

Keywords: additional professional education, pedagogical coaching, selfactualization, self-realization of personality

Компетентностно-ориентированное образование направлено на формирование активной профессиональной и жизненной позиции будущих педагогов [4], позволяющей выработать единую цель-миссию и осуществлять педагогическую деятельность на основе индивидуально-творческого решения профессиональных задач. В ситуации постоянного обновления и изменения содержания образования на первый план выходит необходимость развития личности обучающихся, их самопонимания и творческой самореализации. Творчеству нельзя научить. Однако можно и необходимо создавать условия для творческого обучения. Одним из таких условий, по нашему мнению, является использование новой педагогической технологии - педагогического коучинга.

В России коучинг появился в начале двадцать первого века и нашел свое эффективное применение в бизнес-образовании и управлении человеческими ресурсами, вместе с тем, активно распространяясь на другие образовательные сферы. Согласно У. Голви - основоположнику коучинговой технологии - «коучинг не учит, а помогает учиться». Следовательно, основное предназначение коучинга как педагогической технологии в раскрытии потенциала человека с целью максимального повышения его эффективности.

Философско-психологические основания коучинга заключены, прежде всего, в сократовских методах диалога. В основе «повивального искусства» Сократа тезис о возможности помочь людям понять и не возможности заставить их это сделать. Коучинг - это, в первую очередь, умение задавать вопросы, использовать техники, побуждающие обучающегося к размышлению, к самостоятельному поиску разрешения сложившейся ситуации. Причем вопросы должны быть направлены, во-первых, на понимание ситуации; во-вторых, на понимание того, что могло быть лучше; и, втретьих, на понимание того, как сделать лучше [1, с. 25].

Коучинг базируется на концепции гуманизации образования (А. Маслоу, Г. Олпорт, К. Роджерс и др.), где основополагающей целью образования выступает самоактуализация и самореализация личности обучающегося [2].

Так, педагогический коучинг строится на сочетании принципов осознанности и ответственности. Осознание является следствием усиления и концентрации внимания, результатом способности отбирать и ясно воспринимать значимые факты и информацию, определяя их актуальность и объективность. Ответственность обучающихся в коучинге проявляется в наблюдении за происходящими событиями, анализе возможных вариантов решений, самостоятельном выборе и реализации принятого решения, в повсеместном обсуждении достигнутых результатов. Ответственность заключена в выборе, а выбор подразумевает свободу. Следовательно, принимая на себя ответственность, обучающийся самоактуализируется. «Попробуйте честно спросить с себя ответ за свои поступки и за свой выбор, - писал А. Маслоу - и 
вы обязательно почувствуете ответственность перед собой. А это уже само по себе огромный шаг на пути к самоактуализации».

Обучающему в коучинге не требуется иметь преимуществ в знании предмета, деталей обсуждаемых ситуаций и т.д. Его задача - организовать продуктивный диалог с обучающимся, стимулировать его активность в осознании и переосмыслении имеющегося опыта, реализацию самостоятельно принятых решений, генерацию нового опыта. Так, возникает «парадокс экспертности» (Кларин, 2014), позволяющий раскрепостить взрослого обучающегося, снять барьеры в общении, продемонстрировать уважительное отношение к его личностному опыту и профессиональным компетенциям [3, с. 10].

Широкие возможности для раскрытия педагогического потенциала коучинга как одного из видов инновационной образовательной практики предоставляет система дополнительного профессионального образования.

В дополнительном профессиональном образовании цель обучающего направлена на процесс - помочь учиться, дать возможность обучающемуся развиваться и достигать поставленных целей. Цель обучающегося, в свою очередь, сосредоточена не только на процессе, но также на конкретном результате - на решении предметных задач и достижении личностно-профессиональных целей [5].

Элементы педагогического коучинга были апробированы нами в Приднестровском государственном университете имени Т.Г. Шевченко при реализации дополнительной к высшему профессиональной образовательной программы «Преподаватель». По данной программе осуществляется психолого-педагогическая подготовка обучающихся по направлениям «Математика», «Биология», «География», «История», предоставляющая возможность ведения педагогической деятельности в учреждениях образования.

Значительные сложности возникают на первых этапах освоения дополнительной профессиональной образовательной программы и заключаются в низкой мотивации обучающихся. У $20 \%$ студентов сформирована негативная установка на усвоение дополнительной программы - «Мне это не пригодится», «Я не хочу работать в школе». Около 50\% обучающихся занимают в этой ситуации пассивную образовательную позицию и приступают к освоению дополнительной программы, потому что «так нужно».

Сложнейшую задачу - замотивировать обучающихся на личностный и профессиональный рост - решаем посредством введения в образовательный процесс элементов коучинга. Через коммуникативное взаимодействие, систему вопросов возможно помочь обучающемуся четко сформулировать свои ценности и цели, определить образовательные потребности, найти в своей «зоне ближайшего развития» ресурсы для последовательного достижения поставленных целей.

Основной коучинговой моделью, применяемой на занятиях, выступает методика GROW от английского «рост» (М. Дауни). Сущность данной модели заключена в названии: Goal - цель; Realiti - реальность; Options - варианты действий; Wrap-up (Will) - итоги (воля).

Изначально тема последующего занятия не навязывается обучающимся, а определяется ими самостоятельно как логическое продолжение обсуждаемой проблемы. Затем следует определение цели - результата обсуждения, того, что обучающиеся должны вынести из учебного занятия. Следующий этап - открытие реальности - информация по теме обсуждения (какова проблема в действительности, кто занимался ее рассмотрением и т.д.). Основная задача обучающего на данной стадии - задавать вопросы и слушать. Важно не исправлять, не анализировать ответы, не оценивать. Практика показывает, что обучающиеся знают ответы по движению к цели и способны к ней прийти самостоятельно. Далее рассматриваются варианты выбора действий, возможностей, ресурсов - что можно с этим сделать, кто, что, где, зачем. 
Завершающий этап - подведение итогов предполагает ясность и осознанность со стороны обучающихся, принятие на себя ответственности за достижение цели.

Коучинговое обучение в рамках реализации дополнительной к высшему профессиональной образовательной программы «Преподаватель» строится на таких принципах (по М. Эриксону): 1) у каждого обучающегося есть все необходимые ресурсы для достижения своих целей, поэтому каждый может научиться тому, чему он хочет; 2) у каждого действия есть изначально позитивное намерение; 3) в приоритете настоящее и будущее, важно избегать застревания в прошлом; 4) разделение ответственности; 5) отсутствие советов; 6) безоценочная позиция обучающего; 7) экологичная помощь в развитии потенциала обучающихся.

Достижению профессиональной и личной успешности обучающихся в дополнительном профессиональном образовании способствует создание адекватных организационно-педагогических условий, результатом реализации которых, выступает: развитие их коммуникативных, прогностических и организаторских способностей, владение умениями целеполагания, анализа и структурирования информации, эффективное управление временем, умение работать в команде, быстро принимать решения и преодолевать конфликты, ориентироваться на сильные стороны других людей и собственные достижения.

$$
* * *
$$

1. Гуляев В.Н. Педагогический коучинг в профессиональном образовании студента // Актуальные проблемы и перспективы развития профессионально-педагогического образования студентов: Материалы Международной научно-практической конференции. - 2011. - С. 21-26.

2. Зиневич О.В., Петрова Э.Д. Реализация гуманистической модели образования через развитие коучинга // Философия образования. - 2013. - №4 (49). - С. 144-152.

3. Саволайнен Г.С. Коллаборативный коучинг в дополнительном профессиональном образовании педагогов: идея, технология, практика // Вестник Красноярского государственного педагогического университета им. В.П. Астафьева. - 2014. - № 3 (29). - С.6-11.

4. Серякова С.Б. Компетентностный подход в профессиональной подготовке педагогов дополнительного образования // Глобальный научный потенциал. - 2017. № 10 (79). - С.119-121.

5. Серякова С.Б., Кравченко В.В. Дополнительное профессиональное образование в России и странах Западной Европы. Сопоставительный анализ / Монография. - М.: Прометей. - 2016. - 164 с.

\section{Панфилова Е.Е. \\ Методические рекомендации по организации профориентационной работы с обучающимися в системе образования «школа-колледж-ВУЗ»}

Государственный университет управления

(Россия, Москва)

doi 10.18411/spc-04-03-2018-14

idsp 000001:spc-04-03-2018-14

Грамотная организация профориентационной работы в системе образования «школа-колледж-ВУЗ» очень важна в современных условиях развития высокотехнологичных секторов экономики, информационных технологий и новых открывающихся возможностей выстраивания своей профессиональной траектории развития для обучающихся. Приведем ряд методических рекомендаций по организации профориентационной работы с обучающимися, основанных на обобщении практического опыта работы кафедры «Управление организацией в машиностроении» Института отраслевого менеджмента Государственного университета управления (ГУУ):

1. Выделение на кафедре на постоянной основе лица, ответственного за осуществление профориентационной деятельности и набор на образовательные программы бакалавриата и магистратуры. 